MANAGING MULTIPLE IDENTITIES:

DISCOURSE, LEGITIMACY AND RESORCES IN THE UK REFUGEE SYSTEM

\author{
Nelson Phillips and Cynthia Hardy \\ Faculty of Management \\ McGill University \\ 1001 Sherbrooke West \\ Montreal, Canada, H3A 1G5 \\ Tel: (514) 398-3602/4020 \\ Fax: (514) 398-3876 \\ E-mail: phillips@management.mcgill.ca \& hardy@management.mcgill.ca
}

Forthcoming in Organization, March 1997 


\section{MANAGING MULTIPLE IDENTITIES: DISCOURSE, LEGITIMACY AND RESOURCES IN THE UK REFUGEE SYSTEM ${ }^{i}$}

In this article, we examine how the concept of a "refugee" is discursively constituted within the UK refugee system. We examine the actions and interactions of four organizations in particular: the British government, the Refugee Legal Centre, the British Refugee Council and the Refugee Forum, as they struggle to establish an understanding of "refugee" conducive to their goals and interests. Within this institutional field, the social construction of refugees takes place at two different levels: at the broadest level, the idea of a refugee is defined through an ongoing discursive process involving a wide range of actors; while at a more micro level, individual cases are processed by a limited subset of organizations based on this broad definition. We will show that while the government controls the processing of individual cases through its formal authority and control of resources, all four organizations participate in the definition of a refugee and they all, therefore, play a role in refugee determination. Understanding the dynamics of an institutional field requires a consideration of discursive as well as traditional sources of power. While formal authority and resource dependency may provide some organizations with a measure of control within an existing institutional frame, discursive processes enable other organizations to modify or maintain the institutional frame within which traditional power is exercised. 


\section{INTRODUCTION}

In this article, we examine the production of "refugee" as an identity in the UK refugee system. The UK refugee system is an interorganizational domain (Gray, 1989) or institutional field (Warren et al, 1974) in which a number of different organizations participate. We examine the dynamics between four particular organizations: the government, the Refugee Legal Centre, the British Refugee Council, and the Refugee Forum, as they struggle to define "refugee" and to influence the associated practices of refugee determination. Each organization has a particular agenda with respect to refugee determination, and each works to implement this agenda by influencing the resource flows and discursive processes surrounding the "identity" of refugees.

There are two aspects of refugee identity: the production of the idealized conception of what a refugee is; as well as the individual matter of who is and who is not a refugee. The latter process is grounded in the legal practices pertaining to refugee determination and is dominated by the government's access to and management of formal authority and resource dependencies. The former, on the other hand, is not so closely controlled by government and emerges from a discursive struggle between different organizations. In order to understand this process properly, we combine a traditional view of power with a critical discursive approach to examine the complex web of dependencies and discourses that surround the production of refugees.

The paper begins with a description of the UK refugee system. We then introduce critical discourse analysis as a framework for considering the production of refugee as an identity. Using this framework, we then examine the production of refugee identity in some detail, linking the goals of the various organizations to their discursive strategies. Finally, we conclude with a discussion of the role of discourse in the production of institutional fields.

\section{THE UK REFUGEE SYSTEM}

The 1948 United Nations (UN) Universal Declaration of Human Rights asserts that individuals have the right to seek asylum from persecution in other countries. The UN's 1951 Geneva Convention defines refugees as people who have left their own country because of a well-founded fear of persecution for reasons such as race, religion, nationality, political opinion, etc. ${ }^{\text {ii }}$ The "refugee system" represents the policy domain (Laumann \& Knoke, 1987) that determines the status of refugee claimants and assists in the settlement of those individuals granted asylum. It encompasses the formation and implementation of policies and practices that relate to: the rights of individuals to claim asylum; the procedures whereby claimants are awarded asylum; and the support provided to claimants and refugees. It is an interorganizational domain (Gray, 1989) or institutional field (Warren et al, 1974) that includes a number of government, nongovernment and refugee organizations.

The terminology used here is as follows: an asylum-seeker or refugee claimant is an individual seeking asylum; refugee refers to an individual granted asylum whether as a refugee or some other category. Determination refers to the process whereby an individual's status is ascertained. Nongovernment organizations (NGOs) and lawyers who represent and advise claimants concerning their rights in this process are known as protection agencies. Settlement 
refers to the services provided to refugees to help them settle in their new country. It includes training, housing and other support services. Advocacy relates to the political activities of the nongovernment sector. The main organizational actors are government, NGOs, and refugee community organizations (RCOs), which are small, usually ethnic-based refugee-led organizations that engage in a variety of protection, settlement and advocacy on behalf of particular groups of refugees.

In the early 1990s, individuals could apply for asylum on arrival in the UK to an immigration officer or after entry by directly applying to the Immigration and Nationality Department (IND) of the UK's Home Office. Following examination by immigration officials, the determination of individual cases has been the responsibility of the Asylum Division of the IND. Claimants had no formal right to an oral hearing by the decision maker, although they might be interviewed in the course of providing information. Two categories of asylum have existed in the UK: full refugee status and exceptional leave to remain, which accord different rights. The former confers the right to apply for family reunification immediately and permanent residence after four years; the latter group may not apply for family reunification for four years or residence for seven years. If asylum is denied, only those in the country legally have a formal right of appeal to an independent immigration adjudicator. For individuals lacking the correct documentation, there was an internal review process by IND. If these efforts failed, individuals could appeal to the Secretary of State for the Home Office for a final decision. ${ }^{\text {ii }}$

While awaiting their status to be determined, claimants have had the right to legal representation, legal aid, medical and educational services, a work permit, and 90 percent of normal welfare payments. There is no formal government reception program for asylum-seekers as, for example, in Denmark (Hardy, 1994a), and a variety of NGOs provide advice, services, and legal representation to claimants. Neither is there a government settlement program in the UK. So, while the government provides some funding for settlement services through the Home Office's Voluntary Service Unit (VSU), which is not part of IND, the actual provision of services has always been delegated to NGOs and, typically, funds are obtained from a wide variety of different national and local government sources, as well as private charities and trusts. $^{\text {iv }}$

This brief summary of the UK refugee system reveals a number of different stakeholders, of which we examine four in more detail in this paper: the government; the Refugee Legal Centre; the British Refugee Council; the Refugee Forum.

\section{The Government}

The government, especially the Home Office and, within that, the IND, plays a major role in the UK refugee system. It is responsible for drafting and passing refugee legislation which specifies determination procedures and defines the rights of refugees. In the 1990s, the government was active in this role. In 1991, it introduced the Asylum and Immigration Appeals bill which, with its supporting regulations, defined asylum determination procedures and refugees rights in specific legislation for the first time. As a result of the 1992 election, the government withdrew the Bill but a similar version was passed in 1993. 
The IND is responsible for admitting and interviewing asylum-seekers, and determining refugees. This government department implements the government's policy on immigration and nationality which, in 1991/2, included the following: to allow "genuine visitors" to enter the UK and "to restrict severely the numbers" coming to the UK who did not fall into this category (Home Office Report, 1991/2: iii). Its functions include pre-entry, on-entry and after-entry controls; consideration of asylum applications; enforcement of immigration law and the granting of citizenship (Home Office, 1991/2: iv). The Immigration Service, one of two branches of IND, is responsible for admitting, interviewing, and detaining asylum-seekers and also deporting individuals whose claims have been rejected.

The Asylum Division, one of four divisions in the other branch of the IND, Policy and Nationality, makes the decisions on whether claimants are granted refuge or exceptional leave to remain, or are denied asylum. This division was a small unit of less than 100 civil servants until 1991, when plans were announced for a five-fold increase in numbers to deal with growing numbers of asylum applications. The size of the unit jumped from 120 in April 1991 to 460 a year later (Home Office Report, 1991/2). At the same time as the Asylum Division was expanded, new procedures were put into place to speed up processing.

\section{The Refugee Legal Centre (RLC)}

The RLC is an NGO, a registered charity which was initially set up by the government in 1976 as the Refugee Unit, part of a larger, government-funded organization -- the UK Immigrant Advisory Service (UKIAS). In April 1991, following the five-fold increase in the Asylum Division to deal with rising numbers of asylum applications, the government proposed a parallel increase the number of caseworkers in the Refugee Unit, still part of UKIAS at that time, from 15 to over 40. At the time of the announcement of the Asylum and Immigration Appeals Bill in 1991, the government announced plans to end legal aid to refugee claimants and to make the Refugee Unit the sole provider of free legal representation. As a result, asylum-seekers would not be able to go to private solicitors unless they were able to pay for their services. This plan was subsequently dropped. In 1992, the RLC was separated from UKIAS at the instigation of the government, and established as an organization in its own right. A constitution for the new organization was adopted in 1993, following a review by a government-appointed body (the Planning Group). In 1993, the RLC had 45 case workers, up from 15 in 1990, and 88 percent of its budget was government-funded, the remainder coming from the UNHCR.

Since 1992, the RLC has provided free, independent legal representation and advice to asylum-seekers during the determination process. It is virtually the only source of free representation in appeals, for which legal aid has not been made available (Report of the Planning Group, 1993). In addition, it is the only NGO to receive referrals from the Home Office of asylum-seekers who are not legally represented. As a result, while case workers from other NGOs and private lawyers also represent refugee claimants, the vast majority of cases are handled by the RLC. In most cases, then, a case worker from the RLC represents the asylumseeker, while a civil servant from the government's Asylum Division determines the status of that individual. In the event of an appeal of a negative decision, the RLC case worker challenges the Asylum Division's decision directly during the adjudication process. 


\section{The British Refugee Council (BRC)}

The BRC is another NGO. It was formed in December 1981 as a merger of two other agencies to provide a focal point for aid to refugees and to develop its own direct services. Its objectives are to give practical help and promote refugee rights in the UK and abroad. It is also a government-funded charity (about 60 percent of a budget of some five million pounds comes from the government) and it employs around 200 people. The BRC acts as an umbrella organization of over 100 NGOs including well known international charities like Oxfam, Save the Children Fund, the Catholic Fund for Overseas Development. Approximately one third of the membership comprises RCOs. There are four Overseas Committees that address refugee issues in different parts of the world; a UK Policy Committee, and a Finance Committee. Each of these committees may set up working groups to deal with particular matters. The Executive Committee consists of representatives from 18 members, one third of which are RCOs.

The BRC is an active lobby group. It was a founding member of the Asylum Rights Campaign (ARC) which was set up in 1991 to challenge the Asylum and Immigration Appeals Bill. ARC was a consortium, co-chaired by a BRC employee and an RCO member and comprising NGOs, churches, and RCOs, opposed to the Bill's "deterrent" nature. Its remit was "to try to prevent the proposals from becoming law" (Exile: Newsletter of the Refugee Council, 1991(51): 1). The BRC has also actively lobbied for a national settlement policy, in which a centrally coordinated approach to settlement would provide clearly defined services to refugees, although so far to no avail.

\section{The Refugee Forum}

Refugees represent the "output constituency" i.e. those affected by the decisions taken in the domain (Warren et al, 1974). They are powerless (Benard, 1986), often traumatized, alone, unorganized, penniless, and unable to speak English. Even where refugees have organized, these RCOs tend to be small, often employing only four or five people, and under-resourced, living hand-to-mouth on small grants from municipal governments and charitable trusts (see Salinas et al, 1987; Majika, 1991). One such organization is the Refugee Forum, an umbrella association of other RCOs.

The Refugee Forum was formed in 1984 "because of the failures of institutions like the BRC, UKIAS [the United Kingdom Immigrant Advisory Service, of which the RLC's forerunner was a part] and JCWI [the Joint Council for the Welfare of Immigrants, another NGO that provides legal representation and advice] to represent us, to fight for us" (speech by Forum Director, April 1991). Its aims include self organization and self-determination: "helping refugees to help themselves" (Refugee Forum brochure). The Forum, which is neither a charity nor government funded, is an umbrella group of refugee-run organizations which engages primarily in lobbying activities, while its member organizations provide protection and settlement services. In 1990, according to its director, the Forum had 64 branches in the UK and Ireland. It remained, however, a loosely federated network operating on a small budget with only two full time employees. 
The Forum advocates self-help, refugee empowerment, and direct funding to refugee-led organizations. As such, it emphasizes a grassroots approach where refugees take charge of their own destiny, rather than rely on the established (often white-run) agencies. "Gone are the days when we sit with the begging bowl, waiting for institutionalized agencies with their missionary mentalities" (employee). It is, for example, closely linked to the African Refugee Housing Action Group (ARHAG), a charity established in 1979, to provide housing for African refugees based on self-help principles. The Refugee Forum actively distances itself from the more established NGOs which it sees as a threat to refugee organization and self-help: consequently most of its members are not also members of the BRC. Also, unlike the more established NGOs, the Refugee Forum advocates, publicly and privately, helping individuals denied refugee status "go underground", becoming illegal aliens in order to avoid deportation. v

In summary, the four organizations described above all play a role and have a stake in the refugee system. Within this institutional field, these organizations engage in complex dynamics of both collaboration and conflict. The government is largely responsible for determining the status of individual refugees as well as formulating the policies and procedures which specify refugees' rights. The RLC is responsible for representing individual refugees during the determination process, often in direct challenge to the government. But, at the same time, is dependent on government funding and has worked with the government to introduce new determination procedures. The BRC provides a variety of services to refugees and has opposed the government on many of its legislative initiatives. Yet, the BRC also depends on government funding and work worked with government officials on particular projects, such as the reception of Bosnian refugees. The Refugee Forum, like the RLC and BRC, represents refugees and frequently opposes the government. At the same time, it also vehemently opposes these "established" agencies.

Given these conflicting interests, ${ }^{\mathrm{vi}}$ a political analysis seems warranted if we are to understand the refugee system. Obviously, the distribution of power between these groups is not equal. In the UK, both policy making and determination decisions are particularly centralized, within the confines of the Home Office (Hardy, 1994a; also see Cohen, 1994). The government has access to scarce resources and information that other stakeholders do not. Many NGOs depend on government funding, and all refugees depend on government decisions for asylum. Compared to refugees and NGOs, the government would appear to be the dominant stakeholder if we rely on a traditional view of power as derived from resource dependencies or formal authority (e.g. Pettigrew, 1973; Pfeffer \& Salancik, 1974, 1978; Pfeffer, 1981). As we shall see, however, despite its access to and control over scarce resources, as well as its formal authority, the government cannot control the refugee system. To understand better the dynamics of this system, we need to explore the role of discursive processes. In the next section, we examine discourse analysis and show how it is relevant to this study.

\section{THE ROLE OF DISCURSIVE PROCESSES IN THE UK REFUGEE SYSTEM}

Understanding the UK refugee system requires an understanding of how the idea of a refugee is negotiated and how this idea is applied to individual cases through specific 
determination practices. In this section we discuss critical discourse analysis and show its relevance to these dynamics.

The term discourse has a range of meanings within social studies (see Potter \& Weatherell, 1987). As we use the term here, a discourse is a set of statements that brings an object or set of objects into being (Parker, 1992: 5). For example, the discourse of psychology brought into being a whole different understanding of madness, its causes, and its treatment. The unconscious appeared early on in this discourse, brought into being by a set of texts that allowed the unconscious to be discussed, examined, and behaviour to be interpreted based on its existence (Foucault, 1965). Similarly, the discourse around AIDS produced a new social object that made sense of a set of symptoms and diseases previously thought to be unconnected. The medical and social discourse surrounding AIDS continues to encompass a massive struggle over the nature and appropriate response to this new object.

According to Parker, we do not find discourses as such. Instead, we find pieces of them, traces and cues (Fairclough, 1992) to the processes whereby discourses are constituted in texts, "delimited tissues of meaning reproduced in any form that can be given an interpretive gloss" (Parker, 1992: 6). We can, then, treat objects of study as texts. Discourses are realized by means of texts but they are more than texts, they also include the structures and practices that underlie the texts and their production, transmission, and reception (Fairclough, 1992: 57). So, while for writers like Foucault, discourses and practices are the same thing; and while material practices are always invested with meaning while speaking and writing are practices, it is useful "to identify a distinction between physical order and meanings ... and it is helpful to hold onto a conceptual distinction between meanings, the expressive, and physical changes, the practical order (Parker, 1992: 17). Within the context of the UK refugee system, we distinguish between the meaning of a refugee, the idea of what a refugee is, and the practical aspects of determining, at the individual level, who is or is not a refugee.

If we examine discourses, we find they often draw on other discourses for practices which then become part of the new discourse. For example, the AIDS discourse brings together ways of speaking that are associated with the political, medical, scientific, moral, and economic discourses. The discourse surrounding AIDS depends on a high degree of interdiscursivity to provide the many ways of talking available to the participants in the discourse. The way they are brought together and used to structure the discourse surrounding AIDS constitutes the discursive structure of the AIDS discourse. In the case of the UK refugee system, discourses that produce a refugee draw on other discourses (the UN's Universal Declaration of Human Rights, for example), and includes a wide range of texts including government reports and statements, news reports, cartoons, editorials, and demonstrations. This broad range of texts produces an object, the refugee, which changes over time as the discourse changes.

Underlying the above discussion is a strong argument for the active role of discourse in the creation of social reality: discourses create ways of understanding the world; they do not mirror reality. Discourses do not reveal some hidden, pre-constituted reality, but rather provide concepts, objects and subject positions that actors use to fashion a social world. The idea that language has a role in the constitution of reality has, of course, become a commonplace in a wide 
segment of social studies primarily as a result of work in social constructionism and natural language philosophy (Berger \& Luckmann, 1966; Winch, 1958; Wittgenstein, 1957). The idea that words divide up the world, and not the reverse, has been argued by a group of social theorists for decades. The influence of these ideas has also been widespread in organizational analysis with perhaps the most clear links to institutional theory (e.g. Meyer \& Rowan, 1977). The theoretical position developed here is, therefore, an extension of ideas that are already current and well-understood in organizational analysis generally, and in organizational theory in particular. Nor for that matter is discourse analysis unknown in matters of race and immigration (e.g. Potter \& Weatherell, 1987).

But what kinds of things are constituted in discourse? For our purposes here, it is useful to differentiate between three kinds entities constructed in discourse: concepts; objects; subject positions (Fairclough, 1992: 64; Parker, 1992: 6-8).

\section{Concepts}

Concepts are the categories, relationships, and theories through which we understand the world and relate to one another. Concepts make up what Harré (1979) refers to as the expressive sphere: all of the conceptual ideas that make up our cultural background. From the point of view of discourse analysis, concepts are all of the constructions that arise out of structured sets of texts and that exist solely in the realm of ideas. They are more or less contested, and are culturally and historically situated. They are the fundamental ideas that underlie our understandings and relations with one another

Concepts are historically contingent constructions that arise out of a discourse consisting of the texts produced, disseminated, and interpreted by a set of actors in a social situation. Concepts depend on the ongoing construction of texts for meaning and they may therefore change dramatically over time and from social group to social group. Also, since the meaning of a concept is dependent on discourse, and since individual understandings of the world depend on these concepts, participation in the discourse is a political act as discursive acts that succeed in transforming concepts change the world as it is understood. Discursive acts that are intended to redefine concepts are attempts to fashion preferable social relations, which depend for their success on the resources available to the actor producing the text.

Implicit in discursive concepts are ideas of "rightness", what Bakhtin refers to as the "accent" of the concept (Gardiner, 1992: 15). In other words, concepts carry with them a moral evaluation. This accent is part of the ongoing discursive accomplishment of the concept. Accent is open to conflict and ambiguity and is an important part of the political struggle over the concept. Accent is also unstable and open to inversion by groups as they struggle to redefine concepts in ways which change the patterns of social privilege that exist at any point in time (Oliver, 1992).

The idea of a refugee (a "refugee") is a concept. Originally defined by the UN, it continues to be negotiated over time and is changed on an ongoing basis as new texts are produced and added to the existing discourse. The concept of a refugee relates to what a refugee 
is in its idealized sense. It results from earlier international agreements like the Geneva Convention and, implicit in the accent of that concept are the rights and protections for which refugees qualify as well as the obligations of countries to provide them.

\section{Objects}

When concepts are brought into play to make sense of social relations or physical objects, the discourse constitutes an object. Objects and concepts are obviously closely related. The primary difference is the fact that concepts exist only in the expressive order; they exist in the realm of ideas. Objects, on the other hand, are part of the practical order; they are real in the sense of existing in the material world. The concept of a refugee exists in our minds, but the refugee who appears before an immigration office is an object, made sensible, given meaning, by the concept "refugee". The individual has a certain existence outside of the discourse that reveals it; the person has an ontological reality beyond the discourse and would continue to exist in a physical sense apart from others' experience of it (e.g. Laclau \& Mouffe, 1987). The person still exists whether she is a refugee, a tourist, or an illegal immigrant. However, as the concept of a refugee is applied by the immigration officer, by civil servants in the asylum division, by members of NGOs, or by the public, it changes the way the individual is seen and, in particular, the sets of material practices that are invoked. So, while the tourist is admitted and the illegal alien is detained and deported, the refugee is directed towards a determination process to see whether she is, indeed, a refugee.

In this way, concept and object are inter-related: changing the concept fundamentally changes the way the object is socially accomplished. The determination procedures, the protections accorded to the individual object, the services that will be provided depend on the concept of what a refugee is. If our idea of what a refugee is changes, so too do the processes, practices, and structures on which it is based and, ultimately, so does the object, the individual. It is at this level that discourse has the greatest impact on the social world and the greatest interest for organizational researchers. In this way a discourse creates subjects; by making "available a space for particular types of self to step in” (Parker, 1992: 10).

Discourse analysis thus challenges traditional models that view the self as a stable entity. Accordingly, when individuals participate in particular discourses, they act to construct their own subjectivities (Gergen, 1991; Rorty, 1989). Subjects do not join in social interaction as fully formed subjects, as independent and stable "selves" that affect interaction but remain unaffected in turn. Instead, subjects are “decentered” (Fairclough, 1992: 44-45; Gardiner, 1992; Potter \& Wetherell, 1987) and "fragmented" (Cohen, 1994). They are a product of interaction and are continuously re-created through discourse. From this perspective, then, a "self" is the result of a set of contending discourses: "selves" are a discursive product growing out of social interaction (Gardiner, 1992: 72). The self, no less than institutions or other social structures, are social products and are therefore historically and culturally contingent, emerging from the ongoing struggle that characterizes and categorizes social reality. Instead of asking what is the "true" nature of the self, we should examine how it is talked about in discourse (Potter \& Weatherell, 1987). 


\section{Subject Positions}

A subject or self is not just created through discourse, it is also given rights, which Potter \& Weatherell (1987) call "warranting voice”. We are positioned as a subject with regard to the rights we have to speak in the discourse (Laclau \& Mouffe, 1987; Potter, 1992). Theorists such as Foucault (1972) assert that limited numbers of positions exist within discourses from which individuals can speak and act. Statements are not, therefore, a product of independently acting subjects. Instead, subject positions are a function of the discourse and to be able to speak within a discourse requires the actor to take up one of the subject positions. Statements therefore can be thought of as positioning the subjects that produce them in particular ways: "to describe a formulation qua statement does not consist in analyzing the relations between the author and what he says (or wanted to say, or said without wanting to); but in determining what position can and must be occupied by any individual if he is to be the subject of it” (Foucault, 1972: 95-96).

Discourse does not position only subjects in the sense of potential actors within the discourse; the interpreter of a text is no less dependent on the discourse. According to Althusser (1971), texts "hail" their interpreter and thereby shape the position from which the interpreter interprets the text. The discourse creates a social world of a particular kind by making assumptions about the interpreter that become taken-for-granted in the act of interpretation. For example, interpreting an advertisement positions the interpreter as a consumer in a world made up of the consumption and production of material goods: “Ads create an 'alreadyness' of 'facts' about ourselves as individuals: that we are consumers, that we have certain values, that we will freely buy things, consume, and so on. We are trapped in an illusion of choice" (Williamson, 1978: 42). The available roles are limited and circumscribed, and the discourse acts to shape the subjective experience and actions of the participants.

Strategically invoking a discourse has consequences for the speaker as well as for the various receivers of the text. In defining and circumscribing positions from which subjects can speak, act, and interpret as well as the resources available to do so, discourse captures producer as effectively as participants and audience. In fact, there is no clear delineation between producer, participant and audience: in promoting a particular discourse, producers become written into it; in acting out their scripts, participants change them; in receiving and interpreting discursive communication, audiences contribute to them. Accordingly, in the case of refugee discourse, it is not just refugees that are produced so, too, are the immigration officers who admit them; the decision makers who determine their status; the members of NGOs who provide them with services; the media which report on them; the public who reads about them. The organizations involved also construct their organizational "subjectivities" or, as we refer here, their identities, through their discursive activities.

In this way, discourses reproduce and transform institutional structures (Parker, 1992). Accordingly, as Fairclough (1992) notes, the "realities" of the social world do not merely emanate from people's heads: people are confronted with the concrete practices, relations and identities previously constituted in discourse and reified into institutions and practices. So, as the various organizations define what a refugee is and specify their rights and privileges, they define their own role and position in that discourse and contribute to the practices, such as the 
determination process, legislation, service provision, that support and define the institutional field that comprises the refugee system: "Thus the discursive constitution of society does not emanate from a free play of ideas in peoples heads but from a social practice which is firmly rooted in and oriented to real, material social structures" (Fairclough, 1992: 66). The production of refugees, like the production of other social categories, is bound up in a tremendously complex mix of social practices that includes talk but also all of the other processes of categorization and identification. All of these activities together produce society.

\section{Discourse and Power}

Individuals and organizations are locked into positions by way of the linguistic practices available to them to make sense of a situation. In using a particular discourse which embraces a particular self, actors not only secure the right to speak but they maintain or challenge power relations (Potter and Weatherell, 1987). Consequently, discourses reproduce and transform power relations and are, therefore, political processes (Fairclough, 1992; Parker, 1992). So, discourse analysis should involve the examination of different categories of objects, and what the members of those categories stand to gain or lose from the employment of the discourse, and who would want to promote and who would want to dissolve the discourse (Parker, 1992).

Discourse as a political practice establishes, sustains and changes power relations ... Furthermore, discourse as a political practice is not only a site of power struggle, but also a stake in power struggle: discursive practice draws upon conventions which naturalize particular power relations and ideologies, and shape these conventions themselves, and the ways in which they are articulated, are a focus of struggle (Fairclough, 1992: 67).

The existence of a particular concept, the meaning attached to a particular object, the rights of a particular subject position all have political consequences in terms of who is allowed to speak, from what position, and the procedures and practices that are invoked. "Discourse is not simply that which translates struggles or systems of domination but is the thing for which and by which there is struggle, discourse is the power which is to be seized" (Foucault, 1984: 110 quoted in Fairclough, 1992: 51).

\section{“Traditional” Views of Power}

This discussion above presents a very different view of power compared to traditional views, which have focused on formal authority and dependency (see Hardy \& Clegg, 1996). Early writers such as Thompson (1956), Emerson (1962), Mechanic (1962) and Crozier (1964) differentiated power from formal authority and linked it to dependency relations. Work on the strategic contingencies theory of power (Hickson et al, 1971) and resource dependency theory (Pfeffer \& Salancik, 1974, 1978) clarified this relationship, arguing that the ability to control uncertainty and/or critical resources rendered others dependent, thereby conferring power on the individual or organization. Writers specified a variety of resources whose control produced dependency and conferred power (e.g. French \& Raven, 1968: Pettigrew, 1973; Pfeffer, 1981; 
Benfari et al, 1986). Sometimes formal authority is distinguished from resource-based power; sometimes, it is one resource among many.

This traditional or one-dimensional view of power (Lukes, 1974; Clegg, 1989; Hardy, 1994b) is directly challenged by the discursive perspective described here. ${ }^{\text {vii }}$ First, it repudiates the concept of sovereign power where an isolated agent mobilizes a battery of resources to produce particular outcomes. Instead, power is embedded in a network of discourses relations which captures advantaged and disadvantaged alike in its web (Deetz, 1992a,b). Second, it draws attention to how the subject is socially produced by the system of power which surrounds it (Knights \& Willmott, 1989; Knights \& Morgan, 1991; Knights, 1992; Townley, 1993). Identities are salient only insofar as they are socially recognized. Third, it challenges claims to "truth". Instead, each society has its politics of truth: the discourses that it accepts as true; the mechanisms that distinguish truth and falsehood; and the sanctions that are applied to each (Foucault, 1980).

Power, according to this view, is exercised by modifying the discourse that underlies important concepts and/or objects. The act of creating and disseminating texts is therefore a highly political act and underlies the most fundamental struggle for power and control. The result is, not surprisingly, an ambiguous and contested set of discursive structures full of contradiction and subject to continuous negotiation as to their meaning and application. Critical discourse analysis highlights the political aspect of institutional phenomena by resisting the reification of organizations and instead focusing attention on the active role of self-interested stakeholders in the processes through which institutions are produced and maintained. It also focuses attention on the availability of multiple discourses and the usefulness of these multiple and contradictory discursive structures to skilled "entrepreneurs". In the next section, we apply this view of power to the UK refugee system.

\section{POWER AND DISCOURSE IN THE PRODUCTION OF REFUGEES}

It is clear that formal authority and control of resources gives the government control over determination practices. The government is the only actor with the legitimate right to accord refugee status; to apply the concept of a refugee to produce objects -- refugees -- with the rights and privileges that accompany that designation.

[T]he right of asylum historically has always belonged to the state granting such a status, rather than to the individual. This places the state and its representatives in an inherently more powerful position in determining an asylum-seeker's status (Cohen, 1974: 162).

However, the concept of a refugee is, as we shall see, open to challenge and debate. Interested organizations who have limited ability to directly affect the determination process, work to change the concept of a refugee and influence the production of refugees as objects and thereby influence indirectly the determination process. It is here that the perspective developed above helps us to understand the dynamics of the refugee system and to understand how organizations with little power from a traditional viewpoint may still be able to influence the process through 
their interventions in the discursive production of the underlying concepts. The Refugee Forum, for example, has no formal authority, no resources, and few friends within the domain. However, through careful discursive intervention, they bring pressure to bear on the definition of refugee as a concept and can therefore participate in refugee determination despite their marginal status.

Refugee identity -- the concept of a refugee -- is constituted in a complex field of interactions (diagram 1) which includes, but is not confined to, events in other countries; court decisions; the media and public opinion. For example, complex political and economic events across the globe influences the ethnic and political characteristics of refugee flows (Cohen, 1994) and, in turn, how they are seen. The Geneva Convention focused on post-war Europe, Cold War concerns then gave refugee discourse a strong “east-west” dimension; today, many refugees travel from the south to the north to seek asylum (Cohen, 1994). As a result, many refugees are people of colour who, it would appear, evoke different reactions than whites (also see Cohen, 1994). For example, a civil servant noted different perceptions of refugees from Somalia and the former Yugoslavia:

With Yugoslavia, our post bag changed in character. We're getting far more letters in favour of "How can I help and take in a refugee?" .... With Somalia it's a bit different. I don't see many people offering to take in Somalis like they do Yugoslavians. We get people urging the government to help but I've never seen a letter offering to take a Somali into their home while you do get that with Yugoslavians because of the pictures of cuddly, white five year old children. They don't react quite the same way to pictures of starving, black Somali children unfortunately.

This affects not only public opinion but also public policy. This same civil servant noted that events in Yugoslavia would made the passage of the new Asylum Bill more difficult. They added "fuel to the fire that we should adopt an altogether more generous policy" towards refugees. Media coverage of refugees ranges from presenting refugees as individuals who are in need of protection, to mass movements, to statistics, to abusers and scroungers (see Cohen, 1994). The courts often confirm or disconfirm these identities by virtue of particular judgements. For example, in criticizing the government's move to limit the right of appeal of asylum-seekers with false travel documents, a judge wryly noted the following:

He who wishes to obtain asylum in this country, short of a prior contact with the Home Secretary offering him asylum, has the option of lying to the UK authorities in [his] country in order to obtain a tourist or some sort of visa; obtaining a credible forgery of a visa; or obtaining an airline ticket to a third country with a stopover in the UK (Mr Justice Schiemann, quoted in The Times 6 March, 1990).

In summary, refugee identity is constituted at the nexus of many broad influences inside and outside the particular country. Within this broader picture, however, specific organizations also contribute to the production of refugee identities. 
In the next sections, we focus on the four organizations introduced earlier, all of whom have a stake in the refugee system and in the identity of refugees. Often their interests conflict. We will examine how they participate in the construction of the concept of a refugee and, by invoking particular arguments, how they also create their own identity which, in turn, constrains how they manage their relationships with refugees and with other organizations in the field.

\section{“Genuine” and “Economic” Refugees}

One source of conflict draws from discourses of human rights and national sovereignty. In so far as refugees are concerned, there is an irreconcilable tension between these two discourses that divides the government from the remaining three organizations. For government, refugees provoke "a reaction dominated by the notion of state security and the control of immigration, to NGOs it invites a notion of democratic rights and solidarity " (Rudge, 1989: 289). The UK government is considered to be particularly wedded to notions of border control and restricting the access of asylum-seekers (Amnesty International, 1991, 1994; Cohen, 1994; Hardy, 1994a).

We do appreciate the need to stop people coming in to the country because it's the only way to control the situation. We can't give money to everyone... As far as they [the NGOs] are concerned, everyone who comes into the country needs support and ... all the help and advice they can get (civil servant).

Thus, from the government's point of view, refugees represent a potential threat to its agenda of border control and limited access.

We tend to avoid the term "refugee" because that prejudges the result. We prefer the term "asylum" because we deal with people seeking asylum and we have to make a decision whether they are or are not a refugee (civil servant).

Government stakeholders often see those who apply for asylum as "bogus" which leads to the "construction of a new stigmatized group, the 'disguised economic migrant' [which] was necessary to the deconstruction of the morally untouchable category of the 'deserving political refugee"” (Cohen, 1994: 82). For example, a Home Office news release referred to "the large majority of applicants found not to qualify for refugee status" (24/7/90), despite the fact that 87 percent of the 55,000 asylum-seekers between 1979 and 1989 had been granted leave to stay in the country (Hansard, p.719, 26/11/90). Of the 9,660 determinations made in 1989, only 10 percent were rejected as having no legitimate right to stay in the country (figures quoted in Amnesty International, 1991: 5). The government argued that "a growing proportion of this rapidly increasing number of applicants" are not "genuine refugees" but are "motivated primarily by a desire to circumvent normal immigration controls" (see Amnesty International, 1991: 5).

Why does the government promote such an identity? One reason is that, despite its access to resources and formal authority, it is locked into a subject position by a broader immigration discourse that defines "harmonious" race relations in the UK as being dependent on cutting down on the numbers of non white immigrants; a discourse given particular impetus by a 1968 speech by MP Enoch Powell. The promulgation of a refugee identity founded on spurious claims for 
asylum is thus part of a bigger "race card" frequently attributed to Conservative party tactics to secure votes (Cohen, 1994).

The discourse of "economic" or "bogus" refugees invokes a number of practices. One practice is the requirement of visas for visitors to the UK from certain nations to counter, in the words of a UK minister, an increase in the "abuse of asylum claims as a means for securing entry” to the UK (Hansard, 3 March, 1987 col. 732, quoted in Amnesty International, 1991: 31). Another practice is the detention of asylum-seekers: another "necessary" way "to deter people from trying their luck" (1986 Annual Report of the Home Office Refugee Unit, quoted in Amnesty International, 1991: 39). ${ }^{\text {viii }}$

The largest single deterrent is detention, because the bogus applicant is unable to take advantage of the welfare system, he's unable to receive benefits, he's unable to get into accommodation and education and employment. The genuine asylumseeker, it's always seemed to me, that to be housed in what is pretty benevolent detention accommodation ... The genuine asylum-seeker, who's obviously suffered much worse things, if they appreciate that by being detained, a large proportion of the bogus ones will be taken out of the system, or will not even get into it, that their cases will be heard much more quickly and that they will actually have a piece of paper more quickly that says, "You can stay here," as opposed to having ... living in uncertainty for perhaps months, even years -- I think most of the would say, "OK, let's settle for detention” (Peter Tomkins, former head of the Immigration Service, interviewed on BBC Radio Four's File on 4, 18.19.94).

A third practice is the determination system itself: if all claimants are deserving political cases, there would be no need to invoke procedures to weed out false claims. If, on the other hand, many claims are fraudulent, the determination system becomes an obligatory passage point (Callon, 1986) through which all claimants must pass.

Clearly, there are links between the identity of economic refugee and the organizational identity of the IND in particular and the government in general. The role of government in protecting "insiders" from "outsiders", in limiting access to the UK, in developing procedures to "weed out" abusers is reinforced by the concept of the economic refugee. The other three organizations challenge the construction of this refugee identity, partly because their organizational identity is threatened if refugees are economic migrants: their organizational existence rests on providing the support and protection that genuine refugees deserve. So, for example, the BRC promotes such a refugee identity through its lobbying activities and its role in the foundation of the Asylum Rights Campaign to oppose the proposed new Asylum Bill.

Our criticism is not just of the Bill but of a lot of related measures. It's a whole package of measures, some of which are worse than the Bill itself. We are also critical of the climate of opinion that the government and some of the more hysterical of the popular newspapers have created. Labeling asylum-seekers as bogus makes it difficult to believe that they will be treated objectively. If you say all 
the asylum-seekers are bogus and shouldn't be here, it's very difficult to work out a fair way of giving them the right of appeal (member of the BRC)

The Refugee Forum also engaged in a campaign against the new bill. In individual cases, the RLC also challenges government views through its legal representation of asylum-seekers during the determination process. In other words, when the Asylum Division argues that an individual claimant is not a "genuine" refugee, the RLC, in representing that individual, argues the opposite.

In summary, discursive activities by the government, on the one side, and the three NGOs, on the other, two very different refugees identities are constructed: one is of an economic migrant, a bogus claimant, a spurious case; the other is of a deserving individual, a persecuted asylum-seeker, a genuine refugee.

\section{“Dependent” and “Autonomous” Refugees}

Genuine and economic refugees are not the only refugee identities in the making. The four organizations engage in discursive activities to construct other identities and, here, the tensions are more complex. Juxtaposed against each other, and ranging from the helpless to the self-reliant, is the refugee as helpless; as client; as constituent; as capable.

"Dependent" Refugees. For many, the stereotypical view of refugees is as helpless, defenceless individuals, in desperate need of protection and care.

Refugees are a marginalized population. They have left their own state and are now residents of a different state, of which they are not citizens. Their status is regulated by international agreements, but there is no way for the international community to enforce these agreements, much less for the individual refugee, who may not even be aware of their existence, to insist on his or her rights. The situation may change from one moment to the next if there is a shift in the way the war in the refugees' country is going, if the government of the host country changes, or even if that government merely decides to change its refugee policy. The refugee may find himself the subject of multiple powerholders who are at odds with one another: the UN agencies and their local representatives, under orders from Geneva; the representatives of the central government of the host country; the representatives of the local or regional administration, which may be pursuing policies significantly at variance to those of the central government; the representatives of political parties or movements of the refugee's own country or political movement (Benard, 1986: 627).

This identity, seen on television sets in the aftermath of war or following mass displacements of people and associated with the large numbers of refugees huddled in inadequate refugee camps is born of discourses common in development work.

[R]efugees are assumed to be completely helpless and crying out for any assistance that can be given to them. A condition such as this is seen to require direct action and intervention, independent of the participation of, or consultation with, the 
refugees themselves.... [which] deprives refugees of the use of their own coping mechanisms which are so important to re-establish identity, self-esteem and dignity (Needham, 1994: 17).

This identity appears to have traveled with even those refugees who are sufficiently resourceful, connected, rich or simply lucky to arrive in "developed" countries like the UK to claim asylum.

Yet many of the refugees who make it to the UK are well-educated, politically aware, and experienced professionals (Joly \& Cohen, 1989). Despite this the government, it would seem, prefers the identity of a helpless and incompetent refugee.

[A study] looked at the experience of 263 asylum-seekers who had been granted refugee status or been given exceptional leave to remain. Half had to wait more than 16 months for a decision on their cases. It also found that most were well educated -more than a third at degree level -- but had had great difficulty getting work. The research undermined the popular Conservative Party beliefs that most asylumseekers are poverty-stricken economic migrants. [Another] study of voluntary agencies also painted a positive image of asylum-seekers... (The Guardian 4 July, 1994: 1).

Such an identity has a distinct advantage for the government in that it provides further justification of the determination process. The creation of painstaking measures to keep people out of the UK seems misplaced if those individuals are likely to be desirable, contributing members of society. If, on the other hand, they are needy then they will become a "drain" on the country's resources and controls are vindicated to protect indigenous members of society, regardless of humanitarian commitments.

Refugees as “Clients”. For the RLC, refugees have a slightly different identity. They are clients to whom the RLC provides services. Members of the RLC resisted any notion that refugees should control the way in which the RLC administers its services. Those refugees who sit on its board are not there as refugee representatives but overseers of service provision.

Legally they [refugee board members] are charity trustees not representatives. They are there in an individual capacity and their job is to ensure we deliver our services (RLC official).

The Planning Group, which reviewed the RLC and formulated its new constitution, took pains to resist discourses of democracy and accountability (see Report of the Planning Group, 1993). ${ }^{\text {ix }}$

What I found frustrating was that there was too much concentration on the process and on nebulous concepts than on the practical side of things....[refugee] community groups and associations get caught up in the rhetoric of democracy and accountability and independence without really understanding what these mean in practice (Member of Planning Group talking with reference to RLC). 
This particular refugee identity is linked to a particular organizational identity: one which involves a limited political role.

We can participate in the public debate through the normal channels if it directly concerns our clients. My interpretation of the charity laws is they allow us to do that. I don't think we can initiate anything. I don't think we can march down the street and say: "The RLC says down with the Home Secretary". We can certainly participate in the debate on the Asylum Bill but we can't jump on every campaign for every detainee (RLC employee).

But by defining its organizational identity in this way, the RLC faced a number of dilemmas in relation to the other stakeholders. First, the RLC was closely connected to a vocal refugee community, which challenged RLC's political stance. If their subject position allowed them voice, they would be critical of the organization. Consequently, these refugees had to be apolitical clients, and relatively silent clients at that.

I think there's a real problem in the sense that what the refugee organizations say is probably given more weight than other organizations because of political correctness. Now whether what they say is always the best is a moot point.... There's also this perennial problem of a small group of activists who turn up to everything who, because they are from refugee organizations, are deemed to be more vital and more important. I think there's a loss of balance (RLC official).

But, second, in defining the organization as one of case workers dealing with clients, they were viewed with suspicion by other NGOs.

I don't see anyone at the top [of the RLC] thinking politically, strategically. I see some good case workers wanting to protect their clients and do the work, and who get trapped in a situation they can't control (member of another NGO).

This identity raised questions from other NGOs concerning whether the RLC had been coopted by the government, particularly when it was proposed to make the RLC the sole provider of free legal advice and representation to refugees in 1991.

The Home Office doesn't refer everyone to [the RLC]. In other words, it says: "We'll send you people we think have a case". There is an unspoken collusion there at best. What does it say about the other cases who weren't referred. There was a proposal in the new Asylum Bill that [the RLC] would be the sole body for offering legal advice to all refugees. They [refugees] would be denied all other forms of legal advice except [the RLC]. That speaks volumes about the way the government and the Home Office see [the RLC] -- as its tool (BRC employee).

However, a third problem was that to take a more political stand would jeopardize the RLC's relationship with the government, on which it was relatively dependent: it had been given government resources to match the growth in the Asylum Division; and its reorganization and constitution as a separate organization had been instigated by the government. 
Technically we [Home Office] are entirely distinct [from the RLC]: you have an independent organization. Where this falls down in the eyes of the public or of the pressure groups is that it does receive part of its funding from the government and critics say: "How can an organization that receives funding from the government be independent of the government?" We say that ... we have no say in how the organization runs. It's entirely up to them and their constitution how they carry out their work. That also falls down slightly when you consider that we gave them an ultimatum on how to reform themselves and later withdrew their funding on the basis that they didn't do it (civil servant).

In fact, the government and the RLC together worked to construct an organizational identity which put clear limits on the right of the latter to challenge the former.

They [the RLC] undoubtedly do have reservations about aspects of the legislation but at this point it's not going to change. They accept that and try to make the best of it (civil servant).

We've come to the point where we've reached agreement on what we can and can't do. There's not much point in table pounding (RLC official).

However, both parties were aware of the problems that faced the RLC if other stakeholders became overly suspicious of this relationship. Consequently, both government and the RLC engage in discursive activities to combat such accusations and to present an independent identity to other organizations.

The RLC was very alarmed and put out when that proposal [to make it the sole body for offering legal advice to refugees] was included because they thought that really would make them look like government stooges and... it did throw out their relationships with a lot of the NGO community. In order to preserve those relationships, they had to come out and be very critical of us (civil servant).

In summary, we can see that the discursive activities of the RLC help to create both a refugee identity and an organizational identity are produced. These activities are related to the other stakeholders in the domain.

The Refugee "Constituency". While the BRC is also a government-funded charity, its discursive activities create a different refugee identity: refugees are not silent clients but a rather vocal constituency.

There is a different constituency here. We are responsible for asylum-seeking refugees and we are accountable to our membership [which includes refugees]... Our credibility is based on the support and backing of our membership. If we do not voice their concerns we will be dead and so the Home Office has to let us have our say (BRC official). 
These refugees cannot be ignored and this particular concept of a refugee implies quite different practices. So, while the RLC has muted the influence of refugees on its management board, the BRC has extended it. For example, over the last ten years, the BRC has encouraged the membership of RCOs; has amended its constitution to ensure that one third of the members of the its executive committee are representatives of RCOs; has established the Community Development Team, completely staffed by refugees, to help RCOs organize more effectively; and, most recently, established a steering committee for one of its operating divisions -- the Settlement Division -- to ensure the representation and participation of members of the refugee community in the provision of settlement services. ${ }^{\mathrm{x}}$ These practices, in turn, help produce a refugee identity that is capable and powerful. In other words, discourse and practice reinforce each other.

“Autonomous" Refugees. The final identity to be discussed here is that of the autonomous, competent, capable, self-reliant refugee. This is the identity promoted by the Refugee Forum. This refugee does not need the help of the established agencies; in fact this refugee is threatened by the existence of these agencies.

The established institutions have created a divide and rule mechanism. They have been part of the problem -- they cannot be part of the solution. The UNHCR [United National High Commission for Refugees] created divisions by selecting [certain] groups and countries [for resettlement]. The BRC does not give out the money. They take everything and just throw out a few crumbs here and there. And they select who. They actually create refugee groups (refugee member of the Forum).

Another refugee explained, "it's important not to totally depend on the [established] NGOs." because dependency relationship which undermines the ability of the refugee to act.

Accordingly, the organizational identity that is implicated by this refugee identity is one which will have no truck with the established agencies, regardless of how their interests might appear to overlap.

The stories of his aggression are mythical.... [When a white member of another NGO suggested working together more closely] he replied: "It's our experience as black people that if we lie down with dogs, we catch fleas”. It's classic communist party tactics which is to make statements rather than engage in debate. If you engage in debate, it suggests that there is some flexibility in your position... He was willing to deal with the hostility that it engendered because he had a wider and longer term political agenda -- to play off white guilt [by emphasizing] his refugee status and his blackness and his genuine anger (member of another NGO).

Discourse and practice on the part of members of this agency challenge the very existence of the established agencies. Since these are refugees who are criticizing the established agencies, their organizational identities are imperiled. To reclaim space for their role, members of established agencies try to marginalize the Forum. 
The problem lies with the director -- whose strengths are also his weaknesses. He cannot work with anybody, and that's not just the agencies, it is also within the black community .... The greatest loser in all this has been the Refugee Forum itself which is now an extremely marginal group. It's actually nowhere in the campaign and its membership is declining (director of another NGO).

Despite the marginalization and, in fact, because of it, the organizational identity of the Forum was legitimated. For example, many RCOs, as members of the Forum, obviously felt that its existence as a counterpoint to the BRC was crucial to the structure of the domain.

The Refugee Forum is useful. It stems from the grass roots which results in an enormous commitment which is sometimes more effective that BRC. It's more radical so its can't attract a lot of funding while BRC has funding but is bureaucratic. Both have their limits. It's important to have the Forum because it challenges the other system. It provides a check and keeps them honest. Also, it sometimes identifies the real issues because it doesn't make the same assumptions that the BRC does (refugee).

Moreover, in promoting refugee empowerment, the Forum had had a profound influence in pushing more established NGOs, like the BRC, to empower refugees.

I tried to look at [the Forum] as an instrument to get the BRC running around.... the years of criticism made the BRC nervous enough to make changes. A lot of change [in increasing refugee participation], we could say we owe to the Forum indirectly (BRC employee -- a former refugee).

Accordingly, the discourse promoted by the Forum had been a factor in some of the change in practices adopted by the BRC in increasing refugee participation. So, an organization almost devoid of traditional power resources had a significant impact through its use of discursive power.

Some of these quangoes have begun using our language. They say they're creating an "asylum network', talking of a "street-fighting network"(Forum director, quoted at Communities of Resistance Conference, Hackney, London, 1989).

In summary, a variety of conflicting tensions characterize the stakeholders in this domain. In effect, each have a stake in a different refugee identity. For the government, the identity that justifies its approach is not that of a refugee at all but an economic migrant; for NGOs like the RLC, refugees are simply clients; for the BRC refugees are a relatively powerful political constituency; for organizations like the Refugee Forum, refugees are equal partners in society.

\section{CONCLUSIONS}

In this paper, we have examined the discursive construction of refugee identity. That is not to say that we have explored the entire "production process". Given the complexity of the national, and even more so the international, domain, the number of stakeholders, the 
interconnectedness of different discourses, such a research project may be impossible. But we have examined how particular organizations play a role in the construction of refugee identity. We have also shown how the concept of a refugee is different from, but is related to, the decisions regarding the object (i.e. who are refugees) and we have documented some of the influences, in the form of discursive collaboration and discursive conflict between organizations that go towards the construction of refugee identity -- the concept of a refugee -- in the UK. Our research highlights the complexity, not only of the refugee domain, but also of the links between refugee identity, organizational identity and organizational practice. Because discourse has implications for the "speaker" it also produces organizational identities. In addition, refugee identities invoke organizational and interorganizational practices that, in turn, influence both refugee and organizational identity. Finally, we must also emphasize that discursive activities are linked to power in a variety of different ways. First, different identities create or deny opportunities for voice which empowers or disempowers refugees. Second, discursive power may reinforce resource-based power, as in the case of the government's representation of the economic migrant which reinforces its control of the determination system. Third, discursive power may compensate for a lack of traditional power sources such as with the Refugee Forum who was able to secure voice and influence despite having minimal resources. 


\section{REFERENCES}

Althusser, Louis (1971) Lenin and Philosophy and Other Essays. London: New Left Books.

Amnesty International (1991) Deficient Policy and Practice of Asylum Seekers. London: Amnesty International (British Section).

Amnesty International (1994) Asylum-Seekers Detained in the United Kingdom. London: Amnesty International (British Section).

Benard, C. (1986) “Politics and the Refugee Experience”, Political Science Quarterly 101(4): 617-636.

Benfari, R. C., H. E. Wilkinson, \& C. D. Orth (1986) “The Effective Use of Power”, Business Horizons 29(3): 12-16.

Berger, Peter \& Thomas L. Luckmann (1966) The Social Construction of Knowledge: A Treatise on the Sociology of Knowledge, Garden City, NY: Doubleday.

Callon, Michel (1986) "Some Elements of a Sociology of Translation: Domestication of the Scallops and the Fisherman of St. Briene Bay", in John Law (ed), Power, Action and Belief: A Sociology of Knowledge. London: Routledge.

Clegg, Stewart R. (1989) Frameworks of Power. London: Sage.

Cohen, R. (1994) Frontiers of Identity: The British and the Others. London: Longman.

Crozier, Michel (1964) The Bureaucratic Phenomenon. Chicago: University of Chicago Press.

Deetz, Stanley (1992a) Democracy in an Age of Corporate Colonization: Developments in Communication and the Politics of Everyday Life. Albany, NY: State University of New York.

Deetz, Stanley (1992b) “Disciplinary Power in the Modern Corporation”, in Mats Alvesson and Hugh Willmott (eds), Critical Management Studies, pp. 21-45. London: Sage.

Eisenhardt, Kathleen M. (1989) "Building Theories from Case Study Research”, Academy of Management Review 14(3): 532-550.

Emerson, R.M. (1962) “Power-dependence Relations”, American Sociological Review 27(1): 3141.

Fairclough, Norman (1992) Discourse and Social Change, Cambridge, UK: Polity Press.

Foucault, Michel (1972) The Archeology of Knowledge, London: Routledge.

Foucault, Michel (1977) Discipline and Punish: The Birth of the Prison, Harmondsworth: Penguin.

Foucault, Michel (1979) Discipline and Punish: The Birth of the Prison, New York: Vintage Books.

Foucault, Michel (1980) Power/Knowledge: Selected Interviews and Other Writings 1972-1977 (C. Gordon, ed), Brighton: Harvester Press. 
Foucault, Michel (1982) “The Subject and Power”. In H.L. Dreyfus \& P. Rabinow (ed), Michel Foucault: Beyond Structuralism and Hermeneutics. pp. 208-226, Brighton: Harvester.

Foucault, Michel (1984) The History of Sexuality: An Introduction. Harmondsworth: Penguin.

French, J.R.P. \& B. Raven (1968) “The Bases of Social Power”, in D. Cartwright and A. Zander (eds), Group Dynamics. New York: Harper and Row.

Gardiner, Michael (1992) The Dialogics of Critique. London: Routledge.

Gergen, K. 1991. The Saturated Self: Dilemmas of Identity in Contemporary Life. New York: Basic Books.

Goodwin-Gill, G.S. (1983) The Refugee in International Law. Oxford: Clarendon Press.

Gray, Barbara (1989) Collaborating. San Francisco: Jossey-Bass.

Hardy, Cynthia (1994a) "Underorganized Interorganization Domains: The Case of Refugee Systems", Journal of Applied Behavioural Science, forthcoming.

Hardy, Cynthia (1994b) Managing Strategic Action: Mobilizing Change. London: Sage.

Hardy, Cynthia \& Stewart Clegg (1996) “Some Dare Call it Power”, in Stewart Clegg, Cynthia Hardy and Walter Nord, (eds), Handbook of Organization Studies. London: Sage.

Hickson, David J., C.R. Hinings, Charles A. Lee, Rodney E. Schneck, \& Johann M. Pennings (1971) “A Strategic Contingencies Theory of Intraorganizational Power”, Administrative Science Quarterly 16(2): 216-29.

Joly, D. \& P. Cohen (1989) Reluctant Hosts: Europe and Its Refugees. Aldershot, UK: Avebury.

Knights, David (1992) “Changing Spaces: The Disruptive Impact of a New Epistemological Location for the Study of Management, Academy of Management Review, 17(3): 514536.

Knights, David \& Morgan, Gareth (1991) "Strategic Discourse and Subjectivity: Towards a Critical Analysis of Corporate Strategy in Organisations”, Organisation Studies 12(3): 251-273.

Knights, David \& Hugh Willmott (1989) "Power and Subjectivity at Work: From Degradation to Subjugation in Social Relations”, Sociology 23(4): 535-558.

Laclau, Ernesto \& Chantal Mouffe (1987) Hegemony and Socialist Strategy: Towards a Radical Democratic Politics. London: Verso.

Laumann, E.O. \& D. Knoke (1987) The Organizational State. Madison: University of Wisconsin Press.

Lukes, S. (1974) Power: A Radical View. London: Macmillan.

Majika, M. (1991) Into the 1990s: The Needs of Refugee-Based Organizations and Refugees in Britain. Oxford: Refugee Studies Program.

Mechanic, D. (1962) "Sources of Power of Lower Participants in Complex Organizations", Administrative Science Quarterly 7(3), 349-64. 
Meyer, J. W. \& B. Rowan. (1977) “Institutionalized Organizations: Formal Structure as Myth and Ceremony” American Journal of Sociology 83(2): 340-363.

Needham, R. (1994) “Refugee Participation”, Refugee Participation Network \#17, August, Oxford: Refugee Studies Program.

Parker, I. (1992) Discourse Dynamics. London: Routledge.

Pettigrew, A.M. (1973) The Politics of Organizational Decision Making. London, England: Tavistock.

Pfeffer, Jeffrey (1981a) Power in Organizations. Marshfield, MA: Pitman.

Pfeffer, J. \& G. Salancik (1974) "Organizational Decision Making as a Political Process", Administrative Science Quarterly, 19:135-51.

Pfeffer, J. \& G.R. Salancik (1978) The External Control of Organizations. New York: Harper \& Row.

Potter, J. \& M. Wetherell (1987) Discourse and Social Psychology. Newbury Park, CA: Sage.

Report of the Planning Group (1993) Legal Services for Asylum Services: Proposals for the Role and Function of the New Refugee Legal Centre.

Rorty, R. (1989) Contingency, Irony, Solidarity. Cambridge: Cambridge University Press.

Rudge, P. (1989) “The Failure of the Spirit”, Report of the Proceedings of the International Symposium on the Refugee Crisis: British and Canadian Responses: 26-36. Oxford, UK: Refugee Studies Programme.

Said, E. W. (1986) “Foucault and the Imagination of Power”, in David Couzens Hoy (ed), Foucault: A Critical Reader, pp. 149-155, Oxford: Basil Blackwell.

Salinas, M., Pritchard, \& D. Kibedi, A. (1987) Refugee-Based Organizations: Their Function and Importance for the Refugee in Britain. Oxford: Refugee Studies Program.

Sawicki, J. (1991) Disciplining Foucault. London: Routledge.

Thompson, J.D. (1956) “Authority and Power in Identical Organizations”, American Journal of Sociology, 62: 290-301.

Townley, B. (1993) “Foucault, Power/Knowledge, and Its Relevance for Human Resource Management”, American Management Review, 18(3): 518-545.

Walzer, M. (1986) “The Politics of Michel Foucault”, in David Couzens Hoy (ed), Foucault: A Critical Reader, pp. 51-68, Oxford: Basil Blackwell.

Warren, R., Rose, S., \& A. Bergunder (1974) The Structure of Urban Reform. Lexington, MA: DC Heath.

White, S. K. (1986) “Foucault's Challenge to Critical Theory”, American Political Science Review 80(2), 419-432.

Williamson, Judith (1978) Decoding Advertisements: Ideology and Meaning in Advertising. London: Marion Boyers. 
Winch, Peter (1958) The Idea of a Social Science and Its Relation to Philosophy. London: Routledge and Kegan Paul.

Wittgenstein, Ludwig (1967) Philosophical Investigations. Oxford: Blackwell. 


\section{NOTES}

${ }^{\mathrm{i}}$ We would like to thank McGill University and the Social Sciences and Humanities Research Council for their support in this project.

ii The 1967 Protocol Relating to the Status of Refugees, which was signed by nearly 100 countries, modified the Geneva Convention to broaden an European focus, emanating from events during World War Two to take into account events elsewhere in the world (Cohen, 1994). The term "Convention" refugee refers to individuals recognized under these international conventions (see Goodwin-Gill, 1983; Cohen, 1994).

iii This is a somewhat simplified description of the procedures, some of which were amended by the 1993 Asylum and Immigration Appeals Bill, and may be affected by the Asylum and Immigration Bill currently (as of 1996) being considered by the UK Parliament.

iv Although the UK government provides some funding for settlement services, it is not the central player. A variety of other parts of the UK government provide funding to refugees, through race equity, training, employment and other initiatives. Local, municipal government also plays as active role in providing housing, and the London Borough Grants Committee (part of London's municipal government) has been an important source of funding of settlement services, s have a panoply of private charities and trusts.

v Although Cohen (1994: 154-5) found no evidence of the numbers the Refugee Forum claimed to have helped in this regard.

${ }^{v i}$ Note that in discussing interests, we are not talking about objective interests but interests that are constructed as the result of complex ideological, discursive and institutional practices. Such interests are a social product that does not exist independently of the consciousness of their bearers: "precarious historical products which are always subjected to processes of dissolution and redefinition’ (Laclau \& Mouffe, 1987: 97).

vii This approach to power draws on post-modern approaches in general and the work of Foucault (1977, 1980, 1982, 1984) in particular. However, like Fairclough (1992) and others, we provide scope for more agency than many believe Foucault provides (also see Said, 1986; Walzer, 1986; White, 1986; Clegg, 1989; Knights \& Willmott, 1989; Knights \& Morgan, 1991; Sawicki, 1991).

viii Note that Amnesty International has questioned the use of detentions by the government, arguing that such detainees are often bona fide refugees, who have broken no law, and yet have fewer rights than convicted criminals (e.g. Amnesty International, 1991). Another Amnesty International (1994) study of a group of detainees found that the majority were subsequently awarded refugee status. These countervailing views present the identity of refugees as "genuine" asylum-seekers in need of protection. 
ix At this time, a growing feature of NGOs was to have increased representation of members of the community on the management board in order to increase participation, empowerment and accountability.

${ }^{\mathrm{x}}$ In this regard, the steering committee acts much like the management board of a NGO i.e. to ensure the involvement of the community to whom services are provided in the provision of those services. 


\section{University Library}

\section{- M M I E E R VA A gateway to Melbourne's research publications}

Minerva Access is the Institutional Repository of The University of Melbourne

\section{Author/s:}

Phillips, N;Hardy, C

Title:

Managing multiple identities: Discourse, legitimacy and resources in the UK refugee system

\section{Date:}

1997-05-01

\section{Citation:}

Phillips, N. \& Hardy, C. (1997). Managing multiple identities: Discourse, legitimacy and resources in the UK refugee system. ORGANIZATION, 4 (2), pp.159-185. https:// doi.org/10.1177/135050849742002.

Persistent Link:

http://hdl.handle.net/11343/116094 